\title{
Hot melt extruded-based nano zinc as an alternative to the pharmacological dose of $\mathrm{ZnO}$ in weanling piglets
}

\author{
Seung Min Oh${ }^{1, a}$, Min Ju Kim, ${ }^{2, a b d o l r e z a ~ H o s s e i n d o u s t ~}{ }^{2}$, Kwang Yeol Kim², Yo Han Choi ${ }^{3}$, Hyung Bin Ham², \\ Sung Jun Hwang ${ }^{2}$, Jun Hyung Lee ${ }^{2}$, Hyun Jong Cho ${ }^{4}$, Wei Soo Kang, ${ }^{5, *}$ and Byung Jo Chae ${ }^{2, *}$
}

\author{
* Corresponding Authors: \\ Wei Soo Kang \\ Tel: +82-33-250-6494, Fax: +82-33-259-5642 \\ E-mail: kangwiso@kangwon.ac.kr \\ Byung Jo Chae \\ Tel: +82-33-250-8616, Fax: +82-33-244-4946 \\ E-mail: bjchae@kangwon.ac.kr
}

'Gyeongbuk Livestock Research Institute, Yeongju 63052, Korea

2 Department of Animal Resources Science, College of Animal Life Sciences, Kangwon National University, Chuncheon 24341, Korea

${ }^{3}$ Swine Division, National Institute of Animal Science,

Rural Development Administration, Cheonan 31000

Korea

${ }^{4}$ College of pharmacy, Kangwon National University, Chuncheon 24341, Korea

${ }^{5}$ Department of Bio-Health Technology, College of

Bio-Medical Science, Kangwon National University,

Chuncheon 24341, Korea

a These authors contributed equally to this work.

ORCID

Seung Min Oh

https://orcid.org/0000-0001-8848-8028

Min Ju Kim

https://orcid.org/0000-0001-6950-0458

Abdolreza Hosseindoust

https://orcid.org/0000-0001-9191-0613

Kwang Yeol Kim

https://orcid.org/0000-0002-3723-2978

Yo Han Choi

https://orcid.org/0000-0003-4710-4731

Hyung Bin Ham

https://orcid.org/0000-0003-0369-168X

Sung Jun Hwang

https://orcid.org/0000-0003-2071-8645

Jun Hyung Lee

https://orcid.org/0000-0002-7937-7817

Hyun Jong Cho

https://orcid.org/0000-0002-5070-9371

Wei Soo Kang

https://orcid.org/0000-0001-5503-3780

Byung Jo Chae

https://orcid.org/0000-0002-8570-698X

Submitted Feb 19, 2019; Revised May 19, 2019; Accepted Oct 10, 2019
Objective: This study was conducted to investigate the effects of hot-melt extruded $\mathrm{ZnO}$ nano-particles (HME- $\mathrm{ZnO}$ ) as an alternative for $\mathrm{P}-\mathrm{ZnO}$ on growth performance, nutrient digestibility, $\mathrm{Zn}$ bioavailability, intestinal microbiota, and intestinal morphology of weanling pigs.

Methods: A total of 450 piglets (LandracexYorkshirexDuroc) were randomly allotted to five treatments based on initial body weight and sex. The experimental diets were fed in a meal form as phase 1 from $\mathrm{d} 0$ to 14 and phase 2 from d 15 to 28 . Treatments were the control diet without $\mathrm{ZnO}$ supplementation, the diet containing 2,500 ppm $\mathrm{Zn}$ as $\mathrm{ZnO}$, and three diets containing 500, 1,000, or 2,500 ppm Zn as HME-ZnO.

Results: The overall result showed a higher $(\mathrm{p}<0.01)$ average daily gain in weanling pigs fed $\mathrm{ZnO}$-supplemented diets in comparison to the control diet. There was a decrease $(\mathrm{p}<0.01)$ in fecal score in the $\mathrm{ZnO}$-supplemented diets. Dietary supplementation of $\mathrm{ZnO}$ improved $(\mathrm{p}<0.05)$ crude protein digestibility. The weanling pigs fed the $\mathrm{P}-\mathrm{ZnO}$ diet had a lower $(\mathrm{p}<$ $0.01) \mathrm{Zn}$ digestibility in the feces than HME-ZnO supplemented treatments. Weanling pigs fed diets supplemented with $\mathrm{ZnO}$ had greater $(\mathrm{p}<0.05)$ Lactobacillus spp. populations and lower Clostridium spp. $(\mathrm{p}<0.05)$ and Coliforms $(\mathrm{p}<0.01)$ populations in the ileum. Weanling pigs fed diets supplemented with increasing concentrations of HME-ZnO linearly decreased Clostridium spp. $(\mathrm{p}<0.05)$ and Coliforms $(\mathrm{p}<0.01)$ in the ileum. Lower $(\mathrm{p}<0.05)$ Clostridium spp. and Coliforms counts in the colon were observed in pigs fed with $\mathrm{ZnO}$-supplemented diets. Weanling pigs fed diets supplemented with $\mathrm{ZnO}$ showed a greater $(\mathrm{p}<0.01)$ villus height in the duodenum.

Conclusion: Dietary supplementation of $\mathrm{HME}-\mathrm{ZnO}$ and $\mathrm{P}-\mathrm{ZnO}$ showed a potential to improve the digestibility of protein, intestinal Coliform and Clostridium, villus height in duodenum and ileum. Moreover, HME-ZnO showed a higher $\mathrm{Zn}$ digestibility compared with P-ZnO.

Keywords: Nano Zinc; Villus Height; Microbiota; Weaned Pigs; Bioavailability

\section{INTRODUCTION}

Diarrhea is a critical stressor in weanling pigs, which often leads to growth depression and post-weaning diarrheic syndrome [1-3]. The high susceptibility to enterotoxigenic Escherchia coli (E. coli) and Clostridium perfringens as the most common infectious agents during weaning may increase the incidence of diarrhea and decrease growth of weanling pigs $[1,4,5]$. In recent years, research has been conducted to find non-antibiotic feed additives, which have the potential to improve gut health and performance of weanling pigs [6,7]. Particularly, after the ban on the utilization of antibiotics in livestock diets, dietary $\mathrm{ZnO}$ supplementation at the pharmacological dose $(2,500$ and $3,000 \mathrm{mg} \mathrm{Zn} / \mathrm{kg})$ has been widely used to improve 
the growth performance and gastrointestinal functions and to markedly alleviate diarrhea in young pigs [6]. However, regarding environmental concerns, many countries in European Union [8] and other countries such as South Korea or Japan legislated the restricted use of $\mathrm{ZnO}$.

Recently, nano-particles have been widely used in food, medicine, and pharmaceutical industries as more active options with higher biological potential than conventional sources due to their smaller size and larger surface area [9]. In simple terms, the particle size of 1 to $100 \mathrm{~nm}$ is defined as nano minerals [9]. In addition, the methods of nano-particle production may affect their biochemical properties as well. Hot melt extrusion (HME) is a continual mixing process applied to melt or solubilize ingredients and medicines by using a mechanical shear inside the matrix of polymer to produce amorphous systems, which improves solubility and increases the bioavailability of nano-particles [9]. To our knowledge, this study is the first report on the bioavailability of nano-ZnO as HME. In this study, Soluplus (BASF, Ludwigshafen, Germany) was applied as the main polymer matrix during HME processing. The amphiphilic properties of Soluplus optimize solubility and bioavailability through the polyethylene glycol, polyvinyl caprolactam, and polyvinyl acetate contents [9]. Soluplus is a copolymer with the capability of deploying as a binder in wet or dry granulation to increase the solubility and dispersion of poorly water-soluble drugs [9]. The Soluplus-included HME manufacturing process can be applied in the animal feed industry to decrease the environmental pollutions through the reduced trace mineral excretion. Therefore, the effects of dietary supplemented $\mathrm{ZnO}$ and hot melt extruded $\mathrm{ZnO}(\mathrm{HME}-\mathrm{ZnO})$ sources were evaluated on growth performance, nutrient digestibility, intestinal morphology, and microbiota in weanling pigs.

\section{MATERIALS AND METHODS}

The experiment was conducted at the facility of Kangwon National University farm and was approved by the Institutional Animal Care and Use Committee of Kangwon National University, Chuncheon, Republic of Korea.

\section{Preparation of $\mathrm{ZnO}$ and $\mathrm{HME}-\mathrm{ZnO}$}

Zinc oxide was purchased from TMC Co., Ltd. (Anyang, Korea). Zinc oxide nano-particles were designed and produced using HME techniques by maintaining optimum processing conditions. The production assay was carried out as suggested in an analytical procedure [9]. In short, the optimum conditions during HME operations were: temperature, $50^{\circ} \mathrm{C}$ to $55^{\circ} \mathrm{C}$; speed of screw, $150 \mathrm{rpm}$; diameter of die, $1.0 \mathrm{~mm}$; production rate, $3 \mathrm{~kg} / \mathrm{h}$. Soluplus (grafted copolymer) and $\mathrm{ZnO}$ were mixed in the proper ratio $(7: 3, \mathrm{w} / \mathrm{w})$ and then extruded by a twin-screw hot-melt extruder (STS-25HS, Hankook
E.M. Ltd., Pyeongtaek, Korea) equipped with a round-shaped die (2 mm diameter) to produce the final product of HME$\mathrm{ZnO}$. The speed of the screw was set at $200 \mathrm{rpm}$ and extrudates were cooled and milled by the HBL-3500S grinder (Samyang Electronics Co., Gunpo, Korea) for pulverization.

\section{Animals, diets, and managements}

A total of 450 piglets (Landrace $\times$ Yorkshire $\times$ Duroc) with average body weight (BW) of $6.86 \pm 0.3 \mathrm{~kg}$ were allotted to five treatments on the basis of initial BW and sex (all male or all female) in a randomized complete block design. There were six replicate pens in each treatment with 15 pigs per pen. Dietary treatments consisted of the control diet without $\mathrm{ZnO}$ supplementation, the diet containing 2,500 ppm $\mathrm{Zn}$ as $\mathrm{ZnO}$, and three diets containing 500, 1,000, or 2,500 ppm $\mathrm{Zn}$ as HME-ZnO (Table 1). Chromic oxide $(2.50 \mathrm{~g} / \mathrm{kg})$ was added in each diet. Corn was replaced by $\mathrm{ZnO}$ sources based on the $\mathrm{ZnO}$ supplementation level in the diet. The experimental diets exceeded the nutrient requirements as suggested by the NRC [10], and were fed in a meal form for two phases (phase 1 from d 0 to 14 and phase 2 from d 15 to 28). The pigs used in the study were housed in partially slotted concrete floor pens with pens with a size of $2.80 \mathrm{~m} \times 5.00 \mathrm{~m}$. All the pens were equipped with a feeder and a nipple drinker to allow ad libitum access to feed and water.

\section{Growth performance and nutrient digestibility}

At the end of each phase, pigs were weighed individually, and feed consumption was measured to calculate average daily gain (ADG), average daily feed intake (ADFI), and gain to feed ratio (G:F). Fecal grab samples were collected during the last $4 \mathrm{~d}$ of each phase to determine the apparent total tract digestibility of dry matter (DM), gross energy (GE), crude protein $(\mathrm{CP})$, and $\mathrm{Zn}$. Pens were cleaned before the start of sample collection and the fecal samples were then pooled within the pen, dried in a forced air oven at $60^{\circ} \mathrm{C}$ for $72 \mathrm{~h}$, and ground in a Wiley mill (Thomas Model 4 Wiley Mill, Thomas Scientific, Swedesboro, NJ, USA) using a 1-mm screen for chemical analysis. Analysis for each sample was done in triplicate for DM (Method 930.15), CP (Method 990.03), ash (Method 942.05), Ca, and P (method 985.01; 16) according to the methods of AOAC [11]. The GE of diets and feces were measured using a bomb calorimeter (Model 1261, Parr Instrument Co., Molin, IL, USA), while Cr concentrations were determined [12] with an automated spectrophotometer (Shimadzu, Japan).

\section{Determination of $\mathrm{Zn}$ contents}

Zinc content (method 985.01) in the feed, feces, and serum was determined on the dissolved ashes prepared by AOAC [11]. One $\mathrm{g}$ of ground feed or fecal sample was ashed for 1 $\mathrm{h}$ in a muffle furnace at $600^{\circ} \mathrm{C}$. Then, the ashed sample was 
Table 1. Formula and chemical composition of control diets (as-fed basis)

\begin{tabular}{|c|c|c|}
\hline Item & $\begin{array}{l}\text { Phase } 1 \\
\text { (d } 0 \text { to 14) }\end{array}$ & $\begin{array}{c}\text { Phase } 2 \\
\text { (d } 15 \text { to } 28 \text { ) }\end{array}$ \\
\hline \multicolumn{3}{|l|}{ Ingredient (g/kg) } \\
\hline Corn & 380.7 & 465.7 \\
\hline Fish meal & 50 & 30 \\
\hline Dehulled soybean meal & 244.9 & 294.9 \\
\hline Whey powder & 170 & 153.8 \\
\hline Fish meal & 50 & 30 \\
\hline Soy protein concentrate & 50 & - \\
\hline Soybean oil & 33.8 & 26 \\
\hline Monocalcium phosphate & 4 & 3.6 \\
\hline Limestone & 7.7 & 8.3 \\
\hline Salt & 3 & 3 \\
\hline DL-methionine & 1.4 & 0.8 \\
\hline L-lysine & 3.3 & 2.8 \\
\hline L-threonine & 1.4 & 1.3 \\
\hline L-tryptophan & 2.2 & 1.7 \\
\hline Vitamin premix ${ }^{1)}$ & 2.5 & 2.5 \\
\hline Mineral premix ${ }^{2)}$ & 2.5 & 2.5 \\
\hline Choline chloride & 0.5 & 0.5 \\
\hline Phytase & 0.1 & 0.1 \\
\hline Chromic oxide & 2.5 & 2.5 \\
\hline Lactose & 39.5 & - \\
\hline Total & 1,000 & 1,000 \\
\hline \multicolumn{3}{|l|}{ Calculated composition (\%) } \\
\hline ME (MJ/kg) & 14.226 & 14.226 \\
\hline$C P$ & 23 & 21 \\
\hline Calcium & 0.8 & 0.7 \\
\hline Available phosphorus & 0.4 & 0.33 \\
\hline SID Lys & 1.35 & 1.23 \\
\hline SID Met & 0.41 & 0.36 \\
\hline SID Met+Cys & 0.74 & 0.68 \\
\hline SID Thr & 0.79 & 0.73 \\
\hline SID Trp & 0.22 & 0.2 \\
\hline Lactose & 15 & 10 \\
\hline
\end{tabular}

ME, metabolizable energy; $C P$, crude protein; SID, standardized ileal digestibility

1) Supplied per kilogram of diet: 20,000 IU vitamin $A, 4,200$ IU vitamin $D_{3}, 10$ IU vitamin $E_{1}, 5.6 \mathrm{mg}$ vitamin $\mathrm{K}_{3}, 2.8 \mathrm{mg}$ vitamin $B_{1}, 5.5 \mathrm{mg}$ vitamin $B_{2}, 4.2 \mathrm{mg}$ vitamin $B_{6}, 0.042 \mathrm{mg}$ vitamin $B_{12}, 14 \mathrm{mg}$ pantothenic acid, $42 \mathrm{mg}$ niacin, 0.105 $\mathrm{mg}$ biotin, $1.05 \mathrm{mg}$ folic acid.

2) Supplied per kilogram of diet: $50 \mathrm{mg} \mathrm{Fe}$ as $\mathrm{FeSO}_{4}, 0.20 \mathrm{mg} \mathrm{Co}$ as $\mathrm{CoSO}_{4}, 30 \mathrm{mg}$ Cu as $\mathrm{CuSO}_{4}, 30 \mathrm{mg} \mathrm{Mn}$ as $\mathrm{MnSO}_{4}, 0.35 \mathrm{mg} \mathrm{I}$ as $\mathrm{Ca}\left(\mathrm{IO}_{3}\right), 0.25 \mathrm{mg}$ Se as $\mathrm{Na}_{2} \mathrm{SeO}_{3}$.

allowed to cool, dissolved by adding $10 \mathrm{~mL} \mathrm{50 \%} \mathrm{HCl}(\mathrm{v} / \mathrm{v})$, and kept covered overnight. For serum samples, a $1 \mathrm{~mL}$ serum sample was measured in porcelain crucible and dried for 4 hours at $105^{\circ} \mathrm{C}$ and then ashed for $1 \mathrm{~h}$ at $600^{\circ} \mathrm{C}$ in a muffle furnace. The samples were filtered using Whatman filter paper No.40 (Whatman, Maidstone, UK) in a $100 \mathrm{~mL}$ volumetric flask by washing crucibles 2 to 3 times and diluted with deionized distilled water. The concentration of $\mathrm{Zn}$ was measured by inductively coupled plasma emission spectroscopy (730ES, Varian, Palo Alto, CA, USA).

\section{Blood collection and immunoglobulin analysis}

A $10 \mathrm{~mL}$ blood sample was collected from two randomly selected pigs from each pen on $\mathrm{d} 14$ and 28 . The sampling was conducted by jugular vein puncture using a disposable vacutainer tube without anticoagulants (Becton Dickinson, Franklin, NJ, USA). The blood samples were then centrifuged by $3,000 \times g$ for $15 \min 4^{\circ} \mathrm{C}$, and separated serum was stored at $-20^{\circ} \mathrm{C}$ until analysis. Immunoglobulin A (IgA), IgG, and IgM of serum were analyzed with immunoglobulin kits (Sanwei Biological Engineering Co., Ltd., Shandong, China), using an automated spectrophotometer (Shimadzu, Japan).

\section{Microbial analyses}

To evaluate the microbial population, on $\mathrm{d} 28$, fresh digesta samples of ileum, cecum, and colon from 2 euthanized pigs (around the average BW) in each pen were collected and kept on ice. One gram of the digesta from ileum, cecum, or colon was diluted with $9 \mathrm{~mL}$ of $1 \%$ peptone broth (Becton, Dickinson and Co., USA) and then homogenized. Viable counts of bacteria in the samples were then conducted by plating serial 10-fold dilutions to determine the total anaerobic bacteria (tryptic soy agar), Lactobacillus spp. (De Man, Rogosa and Sharpe agar) + 0.2 g/L NaN3 + 0.5 g/L L-cystine hydrochloride monohydrate), Clostridium spp. (tryptose sulfite cycloserine [TSC] agar), and Coliform (violet red bile agar) were used. The anaerobic conditions during the assay of total anaerobic bacteria and Clostridium spp. were created by using gas pack anaerobic system (BBL, No. 260678, Difco, Detroit, MI, USA). The tryptic soy agar (No. 236950) and violet red bile agar (No. 216695) were purchased from Difco Laboratories (USA), and TSC agar (CM0589) were purchased from Oxoid (Hampshire, UK). The bacterial concentrations were transformed to log before statistical analysis.

\section{Small intestinal morphology}

To evaluate the small intestinal villus height and crypt depth, on $\mathrm{d} 28$, intestinal samples from euthanized pigs (1 male and 1 female) in each pen were collected. For each intestinal sample, three cross-sections were prepared after staining with azure $\mathrm{A}$ and eosin using standard paraffin embedding procedures [13]. A total of 10 intact, well-oriented crypt-villus units were selected in triplicate for each intestinal cross-section. The measurement of villus height was made from the tip of the villi to the villus-crypt junction, the crypt depth was defined as the depth of the invagination between adjacent villi, and villus width was measured till the middle of the villus. All morphological measurements were made in $10-\mu \mathrm{m}$ increments by using an image processing and analysis system (Optimus software version 6.5, Media Cybergenetics, North Reading, MA, USA). 


\section{Calculations and statistical analysis}

The apparent total tract digestibility was calculated as:

$$
\begin{aligned}
& \text { The apparent total tract digestibility } \\
& =1-\left(\mathrm{Cr}_{\text {diet }} \times \text { nutrient }_{\text {feces }}\right) /\left(\mathrm{Cr}_{\mathrm{feces}} \times \text { nutrient }_{\text {diet }}\right)
\end{aligned}
$$

where, $\mathrm{Cr}_{\text {diet, }}$ chromium content in the diet; nutrient $\mathrm{feces}_{\text {es }}$, nutrient content in the feces; $\mathrm{Cr}_{\text {feces }}$, chromium content in the feces; nutrient $_{\text {diet, }}$ nutrient content in the diet.

Orthogonal contrasts (control vs others; HME- $\mathrm{ZnO}$ vs P$\mathrm{ZnO}$ ) were used to compare the possible relationship between the treatments, using the procedure PROC general linear model of SAS (SAS Inst. Inc., Cary, NC, USA). In addition, orthogonal polynomial contrasts were applied to evaluate the significance of linear or quadratic models to describe the response in increasing dietary HME-ZnO levels $(0,500,1,000$, and $1,500 \mathrm{mg} / \mathrm{kg}$ ). The pen was used as the experimental unit for the analysis of all the parameters. Probability values less than 0.05 were considered as significance.

\section{RESULTS}

\section{Growth performance and fecal score}

Growth performance and fecal score data are presented in Table 2. There was no mortality in this experiment (data not shown). In phase 1 , there was an improvement $(\mathrm{p}<0.01)$ in $\mathrm{ADG}$ and $\mathrm{G}: \mathrm{F}$ in pigs fed $\mathrm{ZnO}$-supplemented diets compared with the control diet. However, there was no difference in ADG, ADFI, and G:F between HME-ZnO and P-ZnO treatments. An increasing concentration of HME- $\mathrm{ZnO}$ in diets resulted in linearly improved $(\mathrm{p}<0.01)$ ADG. In phase 2, Dietary supplementation of $\mathrm{ZnO}$ showed an increased $(\mathrm{p}<0.01)$ $\mathrm{ADG}$ and G:F compared with the control diet. Weanling pigs fed diets supplemented with increasing concentrations of HME-ZnO increased ADG (linear and quadratic, $\mathrm{p}<0.01$ ), and G:F (linear, $\mathrm{p}<0.01$ ). The overall result showed a greater $(\mathrm{p}<0.01)$ ADG and G:F in weanling pigs fed $\mathrm{ZnO}$-supplemented diets in comparison to the control diet. There was no difference in ADG, ADFI, and G:F between the HME$\mathrm{ZnO}$ and $\mathrm{P}-\mathrm{ZnO}$ diets. Weanling pigs fed the HME- $\mathrm{ZnO}$ diets showed a greater ADG (linear and quadratic, $\mathrm{p}<0.05$ ), ADFI (linear, $\mathrm{p}<0.05$ ), and $\mathrm{G}: F$ ratio (linear, $\mathrm{p}<0.01$ ) during overall phase. In phases 1 and 2 , there was a decrease $(p<0.01)$ in fecal score in the $\mathrm{ZnO}$-supplemented diets. Weanling pigs fed $\mathrm{P}-\mathrm{ZnO}$ had a lower fecal score $(\mathrm{p}<0.01)$ compared with the HME-ZnO treatments. The HME-supplemented diets showed reduced fecal score in phase 1 (linear and quadratic, $\mathrm{p}<0.05$ ) and phase 2 (linear, $\mathrm{p}<0.05$ ).

\section{Digestibility of nutrients}

The effects of dietary supplemented Zn source and concentration on nutrient digestibility are shown in Table 3. In phase 1 , there were no differences in digestibility of DM and GE. Dietary supplementation of $\mathrm{ZnO}$ improved $(\mathrm{p}<0.05) \mathrm{CP}$ digestibility compared with the control treatment. However, there was no difference in digestibility of $\mathrm{CP}$ between the $\mathrm{HME}-\mathrm{ZnO}$ and $\mathrm{P}-\mathrm{ZnO}$ treatments. There was a linear increase $(\mathrm{p}<0.01)$ of $\mathrm{CP}$ digestibility by the supplementation of $\mathrm{HME}-\mathrm{ZnO}$ to the diet. In phase 2, there was no difference in digestibility of DM. Weanling pigs fed $\mathrm{ZnO}$-supplemented

\begin{tabular}{|c|c|c|c|c|c|c|c|c|c|c|}
\hline \multirow{2}{*}{ Item } & \multirow{2}{*}{$\mathrm{CL}^{1)}$} & \multicolumn{3}{|c|}{$\mathrm{HME}^{1)}(\mathrm{ppm})$} & \multirow{2}{*}{$\mathrm{P}-\mathrm{Zn} 0^{1)}$} & \multirow{2}{*}{ SEM } & \multicolumn{4}{|c|}{ Contrasts $^{2)}(p$-value) } \\
\hline & & 500 & 1,000 & 2,500 & & & CL vs others & HME vs P-ZnO & L & Q \\
\hline \multicolumn{11}{|c|}{ Phase 1 (0-14 d) } \\
\hline ADFI (g) & 379 & 377 & 393 & 402 & 395 & 10.62 & 0.316 & 0.706 & 0.088 & 0.599 \\
\hline $\mathrm{G}: \mathrm{F}$ & 0.67 & 0.70 & 0.71 & 0.72 & 0.72 & 0.01 & 0.004 & 0.456 & 0.700 & 0.419 \\
\hline \multicolumn{11}{|c|}{ Phase 2 (15-28d) } \\
\hline ADFI (g) & 623 & 635 & 658 & 644 & 657 & 11.68 & 0.065 & 0.391 & 0.073 & 0.195 \\
\hline $\mathrm{G}: \mathrm{F}$ & 0.64 & 0.66 & 0.67 & 0.67 & 0.68 & 0.01 & $<0.001$ & 0.042 & $<0.001$ & 0.074 \\
\hline \multicolumn{11}{|c|}{ Overall (0-28d) } \\
\hline$A D G(g)$ & 327 & 351 & 362 & 362 & 367 & 4.32 & $<0.001$ & 0.137 & $<0.001$ & 0.031 \\
\hline ADFI (g) & 501 & 506 & 526 & 523 & 526 & 8.21 & 0.078 & 0.432 & 0.041 & 0.673 \\
\hline
\end{tabular}

Table 2. Effects of different $\mathrm{ZnO}$ sources on growth performance and fecal score in weanling pigs

$\mathrm{HME}$, hot melt extrusion; SEM, standard error of means; $A D G$, average daily gain; $A D F I$, average daily feed intake; G:F, gain to feed ratio.

1) $\mathrm{CL}$, basal diet without ZnO; HME, basal diet with 500, 1,000, and 2,500 ppm Zn as HME-ZnO; P-ZnO, Basal diet with 2,500 ppm Zn as ZnO.

${ }^{2)}$ Linear $(\mathrm{L})$ and quadratic $(\mathrm{Q})$ effects of HME concentrations.

3) 1 = hard feces, 2 = firm well formed, $3=$ soft and partially formed feces, $4=$ loose, semi-liquid feces, and 5 = watery feces. 
Table 3. Effects of different $\mathrm{ZnO}$ sources on apparent total tract digestibility (\%) of nutrients in weanling pigs

\begin{tabular}{|c|c|c|c|c|c|c|c|c|c|c|}
\hline \multirow{2}{*}{ Item } & \multirow{2}{*}{$\mathrm{CL}^{1)}$} & \multicolumn{3}{|c|}{$\mathrm{HME}^{1)}(\mathrm{ppm})$} & \multirow{2}{*}{$\mathrm{P}-\mathrm{ZnO}{ }^{1)}$} & \multirow{2}{*}{ SEM } & \multicolumn{4}{|c|}{ Contrasts $^{2)}$ ( $p$-value) } \\
\hline & & 500 & 1,000 & 2,500 & & & CL vs others & HME vs P-ZnO & L & Q \\
\hline \multicolumn{11}{|l|}{ Phase I (d 14) } \\
\hline Dry matter & 82.3 & 82.5 & 82.7 & 82.6 & 83.4 & 0.73 & 0.549 & 0.449 & 0.723 & 0.759 \\
\hline Gross energy & 80.1 & 80.7 & 81.1 & 80.7 & 81.7 & 0.43 & 0.096 & 0.093 & 0.217 & 0.222 \\
\hline Crude protein & 76.4 & 76.6 & 78 & 77.9 & 78.2 & 0.45 & 0.012 & 0.161 & 0.005 & 0.677 \\
\hline \multicolumn{11}{|l|}{ Phase II (d 28) } \\
\hline Dry matter & 81 & 81.1 & 81.9 & 81.6 & 82.5 & 0.44 & 0.219 & 0.147 & 0.133 & 0.645 \\
\hline Gross energy & 79.8 & 80.1 & 80.8 & 80.9 & 81.2 & 0.38 & 0.044 & 0.211 & $<0.001$ & 0.797 \\
\hline Crude protein & 75.6 & 77.4 & 77.7 & 78.1 & 77.2 & 0.43 & 0.002 & 0.347 & $<0.001$ & 0.063 \\
\hline
\end{tabular}

HME, hot melt extrusion; SEM, standard error of means.

1) $\mathrm{CL}$, basal diet without ZnO; HME, basal diet with 500, 1,000, and 2,500 ppm Zn as HME-ZnO; P-ZnO, basal diet with 2,500 ppm Zn as ZnO.

2) Linear (L) and quadratic (Q) effects of HME concentrations.

diets showed a greater digestibility of GE $(\mathrm{p}<0.05)$ and $\mathrm{CP}$ $(\mathrm{p}<0.01)$ compared with weanling pigs fed the control diet. There was a linear increase $(\mathrm{p}<0.01)$ in digestibility of GE and $\mathrm{CP}$ as the dietary HME- $\mathrm{ZnO}$ inclusion level increased.

\section{Immunoglobulins}

IgG, IgA, and IgM levels were not affected in weanling pigs fed diets supplemented with $\mathrm{ZnO}$ sources in phase 1 and 2 (Table 4).

\section{$\mathrm{Zn}$ concentrations in feces and serum}

There was an increase $(\mathrm{p}<0.01)$ in the concentration of $\mathrm{Zn}$ in feces with $\mathrm{ZnO}$ supplementation in the diets in both phases (Table 5). The weanling pigs fed the $\mathrm{P}-\mathrm{ZnO}$ diet had a greater $(\mathrm{p}<0.01) \mathrm{Zn}$ concentration in the feces and lower $(\mathrm{p}<0.01)$ $\mathrm{Zn}$ digestibility than HME-ZnO supplemented treatments. In phases 1 and 2 , an increasing concentration of $\mathrm{HME}-\mathrm{ZnO}$ in the diets resulted in linear and quadratic increase $(p<0.01)$ in $\mathrm{Zn}$ concentration in the feces and linear increase $(\mathrm{p}<0.01)$ in $\mathrm{Zn}$ digestibility. Weanling pigs fed the control diet showed a lower $(\mathrm{p}<0.01)$ concentration of $\mathrm{Zn}$ in serum compared with $\mathrm{ZnO}$-supplemented treatments in both phases. However, there were no differences in serum $\mathrm{Zn}$ concentration between $\mathrm{P}-\mathrm{ZnO}$ and $\mathrm{HME}-\mathrm{ZnO}$ treatments. An increasing concentration of HME- $\mathrm{ZnO}$ in the diets resulted in linear (phases 1 and 2) and quadratic (phase 1) increase ( $\mathrm{p}<0.01)$ in Zn concentration in serum.

\section{Intestinal microbiota}

Effects of dietary supplemented $\mathrm{Zn}$ source and concentration on intestinal microbiota are shown in Table 6. No difference was detected in the population of total anaerobic bacteria in the ileum. Weanling pigs fed diets supplemented with $\mathrm{ZnO}$ had greater $(\mathrm{p}<0.01)$ Lactobacillus spp. populations and lower Clostridium spp. and Coliforms populations in the ileum compared with the control. Weanling pigs fed diets supplemented with increasing concentrations of $\mathrm{HME}-\mathrm{ZnO}$ decreased Clostridium spp. (linear and quadratic, $\mathrm{p}<0.05$ ) and Coliforms (linear, $\mathrm{p}<0.01$ ) in the ileum. There were no differences in Lactobacillus spp., Clostridium spp., and Coliforms population in the cecum between pigs fed the $\mathrm{ZnO}$-supplemented diets and the control diet, and also between HME-supplemented and $\mathrm{P}-\mathrm{ZnO}$ treatments. In the cecum, Clostridium spp. population decreased (linear, $\mathrm{p}<0.01$ ) with a dietary

Table 4. Effects of different ZnO sources on the serum immunoglobulins (mg/dL) in weanling pigs

\begin{tabular}{|c|c|c|c|c|c|c|c|c|c|c|}
\hline \multirow{2}{*}{ Item } & \multirow{2}{*}{$\mathrm{CL}^{1)}$} & \multicolumn{3}{|c|}{ HME (ppm) } & \multirow{2}{*}{$\mathrm{P}-\mathrm{ZnO} 0^{1)}$} & \multirow{2}{*}{ SEM } & \multicolumn{4}{|c|}{ Contrasts $^{2)}$ ( $p$-value) } \\
\hline & & 500 & 1,000 & 2,500 & & & $\mathrm{CL}$ vs others & HME vs P-ZnO & $\mathrm{L}$ & $\mathbf{Q}$ \\
\hline \multicolumn{11}{|c|}{ Phase I (d 14) } \\
\hline $\lg G$ & 249 & 238 & 225 & 232 & 236 & 15.5 & 0.652 & 0.811 & 0.321 & 0192 \\
\hline $\lg A$ & 27.2 & 27.5 & 28.7 & 28.6 & 29.5 & 0.57 & 0.077 & 0.112 & 0.112 & 0526 \\
\hline $\lg M$ & 6.25 & 6.75 & 6.67 & 6.75 & 6.50 & 0.27 & 0.185 & 0.451 & 0.185 & 0.623 \\
\hline \multicolumn{11}{|c|}{ Phase II (d 28) } \\
\hline $\lg G$ & 264 & 248 & 242 & 261 & 245 & 14.9 & 0.319 & 0.725 & 0.912 & 0.348 \\
\hline $\lg A$ & 27.9 & 28.9 & 29.7 & 28.6 & 30.2 & 0.53 & 0.087 & 0.259 & 0.522 & 0.205 \\
\hline $\lg M$ & 6.50 & 7.25 & 7.00 & 6.88 & 6.75 & 0.22 & 0.126 & 0.264 & 0.698 & 0.126 \\
\hline
\end{tabular}

HME, hot melt extrusion; SEM, standard error of means; Ig, immunoglobulin.

1) $\mathrm{CL}$, basal diet without ZnO; HME, basal diet with 500, 1,000, and 2,500 ppm Zn as HME-ZnO; P-ZnO, basal diet with 2,500 ppm Zn as ZnO.

2) Linear (L) and quadratic (Q) effects of HME concentrations. 
Table 5. Effects of different ZnO sources on Zn concentration of feces and serum in weanling pigs

\begin{tabular}{|c|c|c|c|c|c|c|c|c|c|c|}
\hline \multirow{2}{*}{ Item } & \multirow{2}{*}{$\mathrm{CL}^{1)}$} & \multicolumn{3}{|c|}{$\mathrm{HME}^{1)}(\mathrm{ppm})$} & \multirow{2}{*}{$\mathrm{P}-\mathrm{ZnO}{ }^{1)}$} & \multirow{2}{*}{ SEM } & \multicolumn{4}{|c|}{ Contrasts $^{2)}$ (p-value) } \\
\hline & & 500 & 1,000 & 2,500 & & & CL vs others & HME vs P-ZnO & $\mathbf{L}$ & Q \\
\hline \multicolumn{11}{|l|}{ Phase I (d 14) } \\
\hline Feed (mg/kg DM) & 179 & 721 & 1,219 & 2,688 & 2,694 & - & - & - & - & - \\
\hline Feces $(\mu \mathrm{g} / \mathrm{g})$ & 1,068 & 4,297 & 6,936 & 13,659 & 17,364 & 173 & $<0.001$ & $<0.001$ & $<0.001$ & $<0.001$ \\
\hline Zn digestibility & 28.1 & 29.2 & 34.2 & 41.6 & 19.0 & 2.7 & 0.181 & $<0.001$ & $<0.001$ & 0.521 \\
\hline Serum $(\mu \mathrm{g} / \mathrm{mL})$ & 1.58 & 2.58 & 2.72 & 2.79 & 2.74 & 0.1 & $<0.001$ & 0.734 & $<0.001$ & $<0.001$ \\
\hline \multicolumn{11}{|l|}{ Phase II (d 28) } \\
\hline Feed (mg/kg DM) & 204 & 730 & 1,211 & 2,628 & 2,699 & - & - & - & - & - \\
\hline Feces $(\mu \mathrm{g} / \mathrm{g})$ & 1,172 & 4,101 & 7,060 & 12,866 & 17,020 & 121 & $<0.001$ & $<0.001$ & $<0.001$ & $<0.001$ \\
\hline Zn digestibility & 32.1 & 34.2 & 30.6 & 44.2 & 20.1 & 2.9 & 0.465 & $<0.001$ & $<0.001$ & 0.479 \\
\hline Serum $(\mu \mathrm{g} / \mathrm{mL})$ & 1.91 & 3.07 & 2.85 & 3.66 & 3.04 & 0.11 & $<0.001$ & 0.249 & $<0.001$ & 0.169 \\
\hline
\end{tabular}

HME, hot melt extrusion; SEM, standard error of means; DM, dry matter.

1) $\mathrm{CL}$, basal diet without ZnO; HME, basal diet with 500, 1,000, and 2,500 ppm Zn as HME-ZnO; P-ZnO, basal diet with 2,500 ppm Zn as ZnO.

2) Linear (L) and quadratic (Q) effects of HME concentrations.

Table 6. Effects of different ZnO sources on intestinal microbial populations (Log10 CFU/g) in weanling pigs (d 28)

\begin{tabular}{|c|c|c|c|c|c|c|c|c|c|c|}
\hline \multirow{2}{*}{ Item } & \multirow{2}{*}{$\mathrm{CL}^{1)}$} & \multicolumn{3}{|c|}{$\mathrm{HME}^{1)}(\mathrm{ppm})$} & \multirow{2}{*}{$\mathrm{P}-\mathrm{ZnO} 0^{1)}$} & \multirow{2}{*}{ SEM } & \multicolumn{4}{|c|}{ Contrasts $^{2)}(p$-value) } \\
\hline & & 500 & 1,000 & 2,500 & & & CL vs others & HME vs $\mathrm{P}-\mathrm{ZnO}$ & $\mathbf{L}$ & Q \\
\hline \multicolumn{11}{|l|}{ Ileum } \\
\hline Total anaerobic bacteria & 7.43 & 7.47 & 7.54 & 7.43 & 7.63 & 0.07 & 0.321 & 0.087 & 0.849 & 0.282 \\
\hline Lactobacillus spp. & 8.27 & 8.45 & 8.57 & 8.41 & 8.53 & 0.06 & 0.019 & 0.536 & 0.125 & 0.041 \\
\hline Clostridium spp. & 5.59 & 5.26 & 5.22 & 5.3 & 5.28 & 0.1 & 0.015 & 0.889 & 0.025 & 0.019 \\
\hline Coliforms & 6.13 & 5.95 & 5.89 & 5.59 & 5.88 & 0.06 & 0.009 & 0.491 & $<0.001$ & 0.339 \\
\hline \multicolumn{11}{|l|}{ Cecum } \\
\hline Total anaerobic bacteria & 8.65 & 8.58 & 8.75 & 8.66 & 8.83 & 0.09 & 0.657 & 0.212 & 0.637 & 0.904 \\
\hline Lactobacillus spp. & 8.25 & 8.32 & 8.4 & 8.38 & 8.45 & 0.11 & 0.407 & 0.609 & 0.375 & 0.735 \\
\hline Clostridium spp. & 6.73 & 6.65 & 6.43 & 6.32 & 6.39 & 0.9 & 0.062 & 0.581 & $<0.001$ & 0.887 \\
\hline Coliforms & 6.38 & 6.3 & 6.18 & 6.28 & 6.11 & 0.14 & 0.382 & 0.481 & 0.495 & 0.518 \\
\hline \multicolumn{11}{|l|}{ Colon } \\
\hline Total anaerobic bacteria & 9.05 & 9.01 & 9.22 & 9.29 & 9.16 & 0.11 & 0.361 & 0.971 & 0.051 & 0.528 \\
\hline Lactobacillus spp. & 8.05 & 8.07 & 8.14 & 8.32 & 8.17 & 0.12 & 0.431 & 0.983 & 0.152 & 0.538 \\
\hline Clostridium spp. & 7.23 & 7.18 & 7.07 & 7.01 & 7.06 & 0.05 & 0.007 & 0.584 & 0.004 & 0.95 \\
\hline Coliforms & 6.89 & 6.78 & 6.67 & 6.69 & 6.65 & 0.08 & 0.028 & 0.457 & 0.081 & 0.465 \\
\hline
\end{tabular}

HME, hot melt extrusion; SEM, standard error of means.

1) $\mathrm{CL}$, basal diet without ZnO; HME, basal diet with 500, 1,000, and 2,500 ppm Zn as HME-ZnO; P-ZnO, basal diet with 2,500 ppm Zn as ZnO.

2) Linear (L) and quadratic (Q) effects of HME concentrations.

increasing concentration of HME-ZnO. Lower $(\mathrm{p}<0.05)$ Clostridium spp. and Coliforms counts in colon were observed in weanling pigs fed with $\mathrm{ZnO}$-supplemented diets than that of pigs fed the control diet. The counts of Clostridium spp. in cecum and colon were linearly decreased $(\mathrm{p}<0.01)$ in weanling pigs fed HME-ZnO diets.

\section{Intestinal morphology}

Effects of dietary supplemented Zn source and concentration on small intestinal morphology are shown in Table 7. Weanling pigs fed diets supplemented with $\mathrm{ZnO}$ showed a greater $(\mathrm{p}<0.01)$ villus height and villus height to crypt depth ratio $(\mathrm{VH} / \mathrm{CD})$ in the duodenum. Weanling pigs fed diets supple- mented with increasing concentrations of HME- $\mathrm{ZnO}$ increased villus height (linear and quadratic, $\mathrm{p}<0.05$ ) and $\mathrm{VH} / \mathrm{CD}$ (linear, $\mathrm{p}<0.01)$ in the duodenum. Weanling pigs diets supplemented with $\mathrm{ZnO}$ increased $(\mathrm{p}<0.05) \mathrm{VH} / \mathrm{CD}$ in the jejunum compared with weanling pigs fed the control diet. There was no difference in villus height and crypt depth in the jejunum between pigs fed $\mathrm{P}-\mathrm{ZnO}$ and $\mathrm{HME}-\mathrm{ZnO}$ diets. In the jejunum, an increasing concentration of HME- $\mathrm{ZnO}$ in diets resulted in linearly improved crypt depth and $\mathrm{VH} / \mathrm{CD}(\mathrm{p}<$ $0.05)$. A greater $(p<0.05)$ villus height in the ileum was observed in weanling pigs fed $\mathrm{ZnO}$ supplemented diets. There was a linear increase $(p<0.01)$ in the villus height of the ileum as the HME- $\mathrm{ZnO}$ inclusion level increased. 
Table 7. Effects of different ZnO sources on small intestinal morphology of weanling pigs (d 28)

\begin{tabular}{|c|c|c|c|c|c|c|c|c|c|c|}
\hline \multirow{2}{*}{ Item ${ }^{1)}$} & \multirow{2}{*}{$\mathrm{CL}^{1)}$} & \multicolumn{3}{|c|}{$\mathrm{HME}^{1)}(\mathrm{ppm})$} & \multirow{2}{*}{$\mathrm{P}-\mathrm{Zn} 0^{1)}$} & \multirow{2}{*}{ SEM } & \multicolumn{4}{|c|}{ Contrasts (p-value) } \\
\hline & & 500 & 1,000 & 2,500 & & & CL vs others & HME vs P-ZnO & $\mathrm{L}$ & Q \\
\hline \multicolumn{11}{|l|}{ Duodenum } \\
\hline Villus height $(\mu \mathrm{m})$ & 423 & 447 & 445 & 445 & 454 & 5.01 & $<0.001$ & 0.186 & 0.01 & 0.029 \\
\hline Crypt depth ( $\mu m)$ & 253 & 247 & 239 & 241 & 243 & 6.28 & 0.139 & 0.913 & 0.131 & 0.424 \\
\hline $\mathrm{VH} / \mathrm{CD}$ & 1.68 & 1.78 & 1.87 & 1.85 & 1.88 & 0.07 & 0.008 & 0.635 & 0.021 & 0.112 \\
\hline \multicolumn{11}{|l|}{ Jejunum } \\
\hline Villus height $(\mu \mathrm{m})$ & 394 & 402 & 412 & 405 & 417 & 4.86 & 0.051 & 0.176 & 0.156 & 0.235 \\
\hline Crypt depth ( $\mu \mathrm{m})$ & 242 & 234 & 224 & 216 & 223 & 8.32 & 0.067 & 0.869 & 0.038 & 0.964 \\
\hline $\mathrm{VH} / \mathrm{CD}$ & 1.63 & 1.72 & 1.85 & 1.87 & 1.87 & 0.06 & 0.011 & 0.448 & 0.011 & 0.696 \\
\hline \multicolumn{11}{|l|}{ Ileum } \\
\hline Villus height $(\mu \mathrm{m})$ & 228 & 230 & 241 & 259 & 245 & 7.88 & 0.047 & 0.804 & 0.006 & 0.307 \\
\hline Crypt depth ( $\mu \mathrm{m})$ & 153 & 145 & 140 & 149 & 141 & 7.18 & 0.251 & 0.669 & 0.654 & 0.268 \\
\hline $\mathrm{VH} / \mathrm{CD}$ & 1.49 & 1.63 & 1.77 & 1.73 & 1.74 & 0.11 & 0.089 & 0.847 & 0.144 & 0.471 \\
\hline
\end{tabular}

HME, hot melt extrusion; SEM, standard error of means; $\mathrm{VH} / \mathrm{CD}$, villus height to crypt depth ratio.

1) $\mathrm{CL}$, basal diet without ZnO; HME, basal diet with 500, 1,000, and 2,500 ppm Zn as HME-ZnO; P-ZnO, basal diet with 2,500 ppm Zn as ZnO.

2) Linear ( $L$ ) and quadratic (Q) effects of HME concentrations.

\section{DISCUSSION}

The greater overall ADG in weanling pigs fed $\mathrm{ZnO}$-supplemented diets could be explained in part by the improved digestibility of nutrients. In addition, the pathogens suppression in the commensal gut microbiota in the intestine, besides a potential promotion of intestinal morphology, may further render nutrients available for weaned pigs by high dietary $\mathrm{ZnO}$ doses supplementation. There are two possible hypotheses that may justify the significant role of $\mathrm{ZnO}$ in improving the growth performance of weanling pigs. Firstly, $\mathrm{Zn}$ is a wellknown anti-stress element and the positive effects on ADG may be explained by the antioxidative role of $\mathrm{Zn}$ as a main contributor to antioxidant enzymes production [14]. Especially that weaning stress is aligned with a high lipid peroxidation and a reduced glutathione peroxidase activity [14]. Therefore, it seems that $\mathrm{Zn}$ requirement can be much higher than the other growing stages and a higher $\mathrm{Zn}$ absorption may trigger the antioxidant capacity of weanling piglets. Secondly, $\mathrm{ZnO}$ has been frequently used as an antimicrobial agent in intestine due to its direct effects on pathogens such as E. Coli [5]. Un-absorbed $\mathrm{ZnO}$ releases to distal sections of intestine and reduce the colonization of pathogens $[5,15]$. Apart from the concentration of $\mathrm{ZnO}$ in the diet, the particle size of $\mathrm{ZnO}$ may be a crucial factor in determining the extent of influence on pathogens. The $\mathrm{ZnO}$ nanoparticle includes high surface area and more active surface than those of a regular size [1618]. Thus, even a lower dose of nano-sized $\mathrm{ZnO}$ may show a similar anti-pathogenic activity as a high dose of $\mathrm{ZnO}$ in regular form. The greater $\mathrm{ADG}$ is in agreement with previous studies which reported that diets containing pharmacological concentration of $\mathrm{Zn}$ as $\mathrm{ZnO}$ led to increased ADG in weanling pigs $[19,20]$. It was reported that the concentration of dietary $\mathrm{Zn}$ at 2,000 ppm as $\mathrm{ZnO}$ enhanced the growth performance of weaned pigs, whereas lower doses at 500 or $1,000 \mathrm{ppm}$ were not effective [21]. This agrees with the results of the present study, where the supplementations of HME-ZnO in pigs diet showed a linear increase in ADG. Previous studies reported that the high dietary $\mathrm{Zn}$ doses (e.g., 2,000 to 3,000 ppm $\mathrm{Zn}$ as $\mathrm{ZnO}$ ) improved growth performance or feed efficiency in pigs $[16,19,20]$. However, in other studies, a high dose of $\mathrm{ZnO}$ had no effect on growth performance $[2,3,5,17]$. The first phase after weaning is the most critical period for pigs mainly because of a sudden change in the diet from milk to solid. However, the greater ADG and G:F in pig fed ZnO-supplemented diets in the second phase emphasize the importance of using the high doses of $\mathrm{ZnO}$ in the phase 2 as well. The results of this study also suggested that using sub-pharmacological dose of HME$\mathrm{ZnO}$ shows no difference in ADG when compared with regular P-ZnO. It also may imply that reducing the dose of $\mathrm{ZnO}$ as HME can be still effective.

Fecal $\mathrm{Zn}$ concentration was greater in pigs fed $\mathrm{ZnO}$-supplemented diets compared with the control. The concentration of $\mathrm{Zn}$ in the feces of weaning pigs fed the diets supplemented with 1,750 or $3,500 \mathrm{mg} / \mathrm{kg}$ of $\mathrm{Zn}$ was consistently greater than that pigs fed the control diet [19]. It was also reported that around 20-fold increase in $\mathrm{Zn}$ excretion has been observed as dietary $\mathrm{Zn}$ increased from 0 to $3,000 \mathrm{mg} / \mathrm{kg}[17,22]$. In the present study, HME- $\mathrm{ZnO}$ was absorbed better than $\mathrm{P}-\mathrm{ZnO}$, which is consistent with the finding of $\mathrm{Li}$ et al [18] that $\mathrm{ZnO}$ digestibility in nanoparticle form was $56 \%$ higher than the conventional $\mathrm{ZnO}$. Nanoparticles have been reported to show a greater absorption rate in the intestine by penetrating small capillaries and beingtaken up by enterocytes $[9,17]$. Our study also has demonstrated that reducing $\mathrm{Zn}$ particles to nanosize 
increases their intestinal uptake. Nano-ZnO possesses lower particle size and larger number of particles per unit, resulting in higher digestibility. High digestibility of $\mathrm{Zn}$ can decrease $Z n$ excretion, consequently reducing the environmental issues. Moreover, the linearly increased serum $\mathrm{Zn}$ level in HME-ZnO treatments is in agreement with Han et al [6], who reported an increase in serum $\mathrm{Zn}$ concentration when pigs fed 1,500 or 2,500 ppm as ZnO. Pieper et al [15] reported that the serum $\mathrm{Zn}$ concentration of pigs fed diets including different levels of $\mathrm{ZnO}$ was the lowest in diets containing $50 \mathrm{mg} / \mathrm{kg} \mathrm{Zn}$, intermediate in diets containing 150 or $250 \mathrm{mg} / \mathrm{kg} \mathrm{Zn}$, and the greatest in diets containing 1,000 or 2,500 mg/kg Zn. Despite a greater digestibility, the serum $\mathrm{Zn}$ concentration was not different between $\mathrm{ZnO}-\mathrm{HME}$ and $\mathrm{P}-\mathrm{ZnO}$ treatments. In this study, we did not evaluate the concentration of $\mathrm{Zn}$ in the liver and kidney, however, the insignificant differences in the serum $\mathrm{Zn}$ concentration between the $\mathrm{HME}-\mathrm{ZnO}$ and inorganic- $\mathrm{ZnO}$ treatments may emphasize the role of storage organs. Plasma Zn concentrations reach a saturation point after using of pharmacological doses of $\mathrm{ZnO}$ in weanling piglets for two weeks and to some extent the excess plasma $\mathrm{Zn}$ renders to the liver and kidney to be stored [23].

In the present trial, pigs fed diets supplemented with $\mathrm{ZnO}$ had greater Lactobacillus spp. in the ileum than pigs fed the control diets, which is in contrast to previous findings [15,17]. In addition, the counts of Coliforms and Clostridium spp. in the ileum of pigs fed $\mathrm{ZnO}$ diets were lower than pigs fed the control diet. A 2,500 ppm $\mathrm{ZnO} / \mathrm{kg}$ diet needs to be supplemented into the diet of weanling pigs to exert anti-diarrhea effects [5]. Even when nano- $\mathrm{ZnO}$ are used, the dietary dosage of $\mathrm{ZnO}$ for diarrhea control is much higher [17] than dietary $\mathrm{Zn}$ recommendations for requirement in standard references [10]. The antibacterial specification of $\mathrm{ZnO}$ is associated with the hydrogen peroxide generation from its surface [24]. Hydrogen peroxide generation may gradually decrease the intestinal $\mathrm{pH}$. A more acidic milieu prevents overgrowth of pathogenic bacteria, such as E. coli, while Lactobacillus spp. can tolerate an acidic environment [25]. The result of this study shows that $\mathrm{ZnO}$ mainly decreases the pathogen (Coliform and Clostridium) populations than Lactobacillus spp. Therefore, it is assumed that $\mathrm{ZnO}$ has the ability to limit pathogen growth and indirectly gives an opportunity for Lactobacillus spp. to proliferate in a less competitive environment. In contrast, another study showed no additional benefits of using $\mathrm{ZnO}$ on ileal Lactobacillus spp. populations, but reported greater ileal total anaerobic bacteria and lower Coliforms population [5]. It has been well established that $\mathrm{ZnO}$ beneficially affects weaned pigs by improving the balance of microbial populations that suppress pathogens like Coliforms $[2,20]$. Another experiment with weaned pigs showed that the number of clostridial clusters were reduced at the pharmacological dose of $\mathrm{Zn}$ at 2,500 ppm as $\mathrm{ZnO}$ was without any effects on Clostridium spp. population when lowering the doses of $\mathrm{Zn}$ to 50, 150, 250, and 1,000 ppm, most likely reflecting a decreased pathogenic bacteria in the ileum of weanling pigs receiving the high $\mathrm{Zn}$ level [15]. The population of Coliforms and Clostridium spp. in the ileum were linearly decreased by increasing dietary HME-ZnO supplementation. The increase of $\mathrm{ZnO}$ surface area by decreasing particle size can increase the antibacterial activity by efficient $\mathrm{H}_{2} \mathrm{O}_{2}$ generation [24]. Yamamoto [26] reported that the decrease in particle size of $\mathrm{ZnO}$ increase the antibacterial activity of $\mathrm{ZnO}$. The result of this study indicates that the sub-pharmacological dose of $\mathrm{HME}-\mathrm{ZnO}$ as well as $\mathrm{P}-\mathrm{ZnO}$ are effective in alleviating pathogen colonization in the proximal sections gastrointestinal tract of weaning piglets.

Post-weaning stress causes transient crypt hyperplasia and villus atrophy during weaning $[1,7]$. The present study indicated that villus height in the duodenum and ileum was improved in $\mathrm{ZnO}$-supplemented diets. Hosseindoust et al [5] demonstrated an increase in dietary $\mathrm{ZnO}$ improved villus height in the duodenum, which might lead to an increased nutrient digestibility in weanling pigs and suggested that $\mathrm{ZnO}$ may affect the morphology and function of the intestine in weanling pigs, resulting in a temporary increase in the intestine surface area by increasing the villus size. Moreover, our results demonstrated that the supplementation of $\mathrm{ZnO}$ into the diet increased the digestibility of $\mathrm{CP}$. Intestinal morphology is an indicator of nutrient digestion, as pigs fed HME-ZnO diets showed a linear increase in digestibility of CP and villus height in the duodenum and ileum. This is in line with the earlier study where digestibility of DM and jejunal villus height were improved in weaned pigs supplemented with the pharmacological dose of $\mathrm{ZnO}[2,20]$. The increase in the digestibility may have been due to improvement in intestinal morphology. This could be beneficial for the weaned pigs because improved intestinal morphology explains proper and rapid absorption of nutrients.

In conclusion, dietary supplementation of $\mathrm{HME}-\mathrm{ZnO}$ and $\mathrm{P}-\mathrm{ZnO}$ improved the performance of weaned pigs, which may be associated with the regulated composition of the gut microflora, and improved digestibility of $\mathrm{CP}$ and intestinal villus height of piglets. In addition, dietary supplementation with sub-pharmacological dose of HME-ZnO may be an alternative to the use of $\mathrm{P}-\mathrm{ZnO}$ due to the insignificant differences in performance and lower $\mathrm{Zn}$ excretion. However, further studies are needed to indicate what dose of HME- $\mathrm{ZnO}$ is the best recommendation for weanling piglets.

\section{CONFLICT OF INTEREST}

We certify that there is no conflict of interest with any financial organization regarding the material discussed in the manuscript. 


\section{ACKNOWLEDGMENTS}

This study was supported by the Kangwon National University research grant (No.520170245).

\section{REFERENCES}

1. Lalles JP, Bosi P, Smidt H, Stokes CR. Weaning-a challenge to gut physiologists. Livest Sci 2007;108:82-93. https://doi. org/10.1016/j.livsci.2007.01.091

2. Mazzoni M, Merialdi G, Sarli G, Trevisi P, Bosi P. Effect of two doses of different zinc sources (inorganic vs. chelated form) on the epithelial proliferative activity and the apoptotic index of intestinal mucosa of early-weaned pigs orally challenged with E. coli K88. Asian-Australas J Anim Sci 2010;23: 777-85. https://doi.org/10.5713/ajas.2010.90352

3. Song YM, Kim MH, Kim HN, et al. Effects of dietary supplementation of lipid-coated zinc oxide on intestinal mucosal morphology and expression of the genes associated with growth and immune function in weanling pigs. Asian-Australas J Anim Sci 2018;31:403-9. https://doi.org/10.5713/ajas.17.0718

4. Zhang Y, Ward TL, Ji F, et al. Effects of zinc sources and levels of zinc amino acid complex on growth performance, hematological and biochemical parameters in weanling pigs. AsianAustralas J Anim Sci 2018;31:1267-74. https://doi.org/10.5713/ ajas.17.0739

5. Hosseindoust AR, Lee SH, Kim JS, et al. Dietary bacteriophages as an alternative for zinc oxide or organic acids to control diarrhoea and improve the performance of weanling piglets. Vet Med 2017;62:52-61. https://doi.org/10.17221/7/2016VETMED

6. Han YK, Thacker PA. Effects of antibiotics, zinc oxide or a rare earth mineral-yeast product on performance, nutrient digestibility and serum parameters in weanling pigs. AsianAustralas J Anim Sci 2010;23:1057-65. https://doi.org/10. 5713/ajas.2010.90569

7. Hosseindoust AR, Lee SH, Kim JS, Choi YH, Kwon IK, Chae BJ. Productive performance of weanling piglets was improved by administration of a mixture of bacteriophages, targeted to control Coliforms and Clostridium spp. shedding in a challenging environment. J Anim Physiol Anim Nutr 2017;101:e98e107. https://doi.org/10.1111/jpn.12567

8. Commission Regulation (EC) No. 1334/2003 of 25 July. Amending the conditions for authorization of a number of additives in feeding stuffs belonging to the group of trace elements. Official Journal of the European Union; 2003.

9. Lee SY, Nam S, Choi Y, et al. Fabrication and characterizations of hot-melt extruded nanocomposites based on zinc sulfate monohydrate and soluplus. Appl Sci 2017;7:902. https:/doi. org/10.3390/app7090902

10. NRC. Nutrient requirements of swine. 11th rev ed. National Research Council. Washington, DC, USA: National Academy
Press; 2012.

11. AOAC. Official methods of analysis. 18th ed. Gaithersburg, MD, USA: Association of Official Analytical Chemists International; 2007.

12. Fenton TW, Fenton M. An improved procedure for the determination of chromic oxide in feed and feces. Can J Anim Sci 1979;59:631-4. https://doi.org/10.4141/cjas79-081

13. Kim J, Shim Y, Ingale SL, et al. The microbial pH-stable exogenous multienzyme improved growth performance and intestinal morphology of weaned pigs fed a corn-soybeanbased diet. J Appl Anim Res 2018;46:559-65. https://doi.org/ 10.1080/09712119.2017.1358628

14. Swain PS, Rao SB, Rajendran D, Dominic G, Selvaraju S. Nano zinc, an alternative to conventional zinc as animal feed supplement: a review. Anim Nutr 2016;2:134-41. https://doi.org/10. 1016/j.aninu.2016.06.003

15. Pieper R, Vahjen W, Neumann K, Van Kessel AG, Zentek J. Dose-dependent effects of dietary zinc oxide on bacterial communities and metabolic profiles in the ileum of weaned pigs. J Anim Physiol Anim Nutr 2012;96:825-33. https://doi. org/10.1111/j.1439-0396.2011.01231.x

16. Kim MJ, Shim Y, Choi Y, et al. Effects of supplementation of hot melt extrusion processed zinc sulfate on growth performance, nutrients digestibility, small intestinal morphologyand excretion of zinc in weanling pigs. Ann Anim Resour Sci 2017; 28:169-79. https://doi.org/10.12718/AARS.2017.28.4.169

17. Milani NC, Sbardella M, Ikeda NY, Arno A, Mascarenhas BC, Miyada VS. Dietary zinc oxide nanoparticles as growth promoter for weanling pigs. Anim Feed Sci Technol 2017;227: 13-23. https://doi.org/10.1016/j.anifeedsci.2017.03.001

18. Li MZ, Huang JT, Tsai YH, Mao SY, Fu CM, Lien TF. Nanosize of zinc oxide and the effects on zinc digestibility, growth performances, immune response and serum parameters of weanling piglets. Anim Sci J 2016;87:1379-85. https://doi.org/10. 1111/asj.12579

19. Walk CL, Wilcock P, Magowan E. Evaluation of the effects of pharmacological zinc oxide and phosphorus source on weaned piglet growth performance, plasma minerals and mineral digestibility. Animal 2015;9:1145-52. https://doi.org/ 10.1017/S175173111500035X

20. Lee S, Hosseindoust A, Goel A, Choi Y, Kwon IK, Chae B. Effects of dietary supplementation of bacteriophage with or without zinc oxide on the performance and gut development of weanling pigs. Ital J Anim Sci 2016;15:412-8. https://doi. org/10.1080/1828051X.2016.1188676

21. Hill GM, Mahan DC, Carter SD, et al. Effect of pharmacological concentrations of zinc oxide with or without the inclusion of an antibacterial agent on nursery pig performance. J Anim Sci 2001;79:934-41. https://doi.org/10.2527/2001.794934x

22. Meyer TA, Lindemann MD, Cromwell GL, Monegue HJ, Inocencio N. Effects of pharmacological levels of zinc as zinc oxide on fecal zinc and mineral excretion in weanling pigs. 
Prof Anim Sci 2002;18:162-8. https://doi.org/10.15232/S10807446(15)31506-0

23. Carlson MS, Hill GM, Link JE. Early-and traditionally weaned nursery pigs benefit from phase-feeding pharmacological concentrations of zinc oxide: effect on metallothionein and mineral concentrations. J Anim Sci 1999;77:1199-207. https:// doi.org/10.2527/1999.7751199x

24. Sawai J, Shoji S, Igarashi H, et al. Hydrogen peroxide as an antibacterial factor in zinc oxide powder slurry. J Ferment Bioeng 1998;86:521-2. https://doi.org/10.1016/S0922-338X
(98)80165-7

25. Heo JM, Opapeju FO, Pluske JR, Kim JC, Hampson DJ, Nyachoti CM. Gastrointestinal health and function in weaned pigs: a review of feeding strategies to control post-weaning diarrhoea without using in-feed antimicrobial compounds. J Anim Physiol Anim Nutr 2013;97:207-37. https://doi.org/ 10.1111/j.1439-0396.2012.01284.x

26. Yamamoto O. Influence of particle size on the antibacterial activity of zinc oxide. Int J Inorg Mater 2001;3:643-6. https:// doi.org/10.1016/S1466-6049(01)00197-0 